\title{
CELLULOSE SHEETS MADE FROM MICRO/NANOFIBRILLATED FIBERS OF BAMBOO, JUTE AND EUCALYPTUS CELLULOSE PULPS
}

\author{
GUSTAVO HENRIQUE DENZIN TONOLI, ${ }^{* * *}$ VANIA APARECIDA DE SA, \\ MARIO GUIMARÃES JR., ${ }^{* * *}$ ALESSANDRA DE SOUZA FONSECA, GREGORY MELVIN GLENN, ${ }^{* *}$ \\ JORDÃO CABRAL MOULIN, ${ }^{*}$ SUHARA PANTHAPULAKKAL, ${ }^{* * * *}$ \\ MOHINI SAIN,${ }^{* * * *, * * * * *}$ DELILAH WOOD, ${ }^{* *}$ TINA WILLIAMS, ${ }^{* *}$ LENNARD TORRES $^{* * *}$ and WILLIAM \\ J. ORTS ${ }^{* *}$ \\ *Department of Forest Science, Federal University of Lavras, C.P. 3037, \\ 37200-000 Lavras, MG, Brazil \\ ***ioproducts Research Unit, WRRC, ARS-USDA, Albany, CA 94710, USA \\ *** Department of Electromechanics, Federal Center for Technological Education of Minas Gerais, Araxá, \\ $M G$, Brazil \\ ${ }^{* * *}$ Center for Biocomposites and Biomaterials Processing, Faculty of Forestry, \\ University of Toronto, Toronto, Ontario M5S 3B3, Canada \\ BUCT, Beijing, China \\ \Corresponding author: Jordão Cabral Moulin,jordao_cm@hotmail.com
}

Received October 30, 2018

\begin{abstract}
The aim of this study was to investigate the properties of cellulose sheets made from fibrillated micro/nanofibrils of bamboo, jute and eucalyptus. Micro/nanofibrils obtained from alkaline-treated jute had higher crystalline fraction (CF) and crystallinity index (CI). The onset degradation temperature $\left(\mathrm{T}_{\text {onset }}\right)$ was very similar for all the micro/nanofibrils (from $316{ }^{\circ} \mathrm{C}$ to $323{ }^{\circ} \mathrm{C}$ ). Defibrillated cellulose nanofibrils had an average diameter in the range of 30-50 $\mathrm{nm}$. Cellulose sheets made of bamboo and jute micro/nanofibrils had higher bending strength, elastic modulus and energy to break than the sheets made of eucalyptus micro/nanofibrils. Compared to the bamboo and jute samples, the eucalyptus micro/nanofibril suspension had a greater amount of fiber debris, which may have contributed to higher apparent porosity, water adsorption and water solubility of the cellulose sheets. Further development of the mechanical defibrillation process could lower the production costs of micro/nanofibrils and improve the performance of engineered cellulose-based materials.
\end{abstract}

Keywords: natural fiber, cellulose nanofibril, mechanical defibrillation process, nanofibril characterization

\section{INTRODUCTION}

Cellulose nanoparticles have been studied for a wide range of applications, such as in biocomposites, where they act as reinforcement for improving mechanical and barrier properties, ${ }^{1-}$ ${ }^{7}$ in paper, ${ }^{8-10}$ paints, coatings, ${ }^{11-12}$ biomedical and pharmaceutical products, ${ }^{13-14}$ fiber-cements, ${ }^{15}$ and in electronic/magnetic devices. ${ }^{16-18}$ Cellulose nanocrystals are commonly obtained by acid hydrolysis by treating cellulose fibers with concentrated sulfuric acid for predetermined conditions of time and temperature. ${ }^{19-20}$ Under these conditions, the amorphous regions of the cellulose are solubilized, leaving single, welldefined cellulose nanocrystals in a stable colloidal suspension. ${ }^{21-22}$ The resulting elongated crystalline rod-like nanostructures are known as 'whiskers' or nanocrystals, which are very effective in reinforcing polymeric matrices. The term 'micro/nanofibrils' refers to long, flexible micro and nanofibers consisting of alternating crystalline and amorphous domains. ${ }^{23}$ Such micro/nanofibrils have previously been obtained by mechanical defibrillation procedures. ${ }^{3,24-25}$

Acid treatment of cellulose fibers induces a rapid decrease in molecular weight through hydrolysis ${ }^{26}$ and requires a considerable effort to properly handle the acid waste. ${ }^{27}$ In contrast, enzymatic hydrolysis of cellulose fibers offers potential advantages because it occurs under much milder conditions and generates little or no 
hazardous waste. Mechanical shear can also be used to produce micro/nanofibrils without generating hazardous waste. In addition to being more environmentally friendly, the high mechanical shear can yield nanoscale fibrils with a high aspect ratio and a higher degree of polymerization than in acid hydrolyzed samples.

Several works reported the production of cellulose micro/nanofibers from wood, ${ }^{24,28-31}$ some non-wood resources, such as bagasse and rice straw, ${ }^{32}$ basts of hemp and flax, ${ }^{1,33-34}$ wheat straw and soy hulls, ${ }^{35}$ stems of cacti, ${ }^{36}$ sisal, $^{37}$ banana rachis, ${ }^{38}$ Aloe vera, ${ }^{39}$ and leaves of sisal and abaca. ${ }^{40}$ Studies were also reported on bamboo, ${ }^{24,41-47}$ however several issues related to the structural changes due to mechanical defibrillation still deserve better investigation. Cellulose paper sheets made of densely packed cellulose nanofibrils have high strength and elastic modulus, ${ }^{48}$ but there is still a lack of information about paper sheets made from jute and bamboo micro/nanofibrils. The aim of this study was to investigate the structural properties of high strength cellulose sheets made from micro/nanofibrils from different plant sources (bamboo, jute and eucalyptus), using a mechanical defibrillation process.

\section{EXPERIMENTAL \\ Materials}

Commercial bamboo cellulose pulps (Bambusa vulgaris Schrad.), 2 years of age, refined and/or unrefined, were obtained from CEPASA - Celulose e Papel de Pernambuco S/A, Jaboatão dos Guararapes, PE, Brazil. Pulps were produced by the sodaanthraquinone process (NaOH-AQ), with approximately $18 \% \mathrm{NaOH}$ and $0.03 \%$ anthraquinone $\left(\mathrm{C}_{14} \mathrm{H}_{8} \mathrm{O}_{2}\right)$ per unit of solid mass contained in the solution, resulting in around $46 \%$ yield of fibers at a $\mathrm{pH}$ between 12-13. After baking in a Pandia continuous digester at a pressure of 6-7 bar and average temperature of $170{ }^{\circ} \mathrm{C}$ for $45 \mathrm{~min}$, the samples were refined in a disk mill and exhibited a Schopper Riegler (SR) number between 25-30.

Jute (Corchorus sp.) macrofibers used in this study were donated by Brasjuta da Amazonia S.A., (Manaus/AM, Brazil). An alkaline treatment was performed on the jute fibers before defibrillation. The long raw jute macrofibers were cut to about $1 \mathrm{~cm}$ length before any pretreatment. In the alkaline process, the jute fibers were treated with $5 \mathrm{wt} \% \mathrm{NaOH}$ solution at a solid to liquid ratio of 1:20 (m/v) for $60 \mathrm{~min}$ at 80 ${ }^{\circ} \mathrm{C}$ under constant stirring ( $\left.355 \mathrm{rpm}\right)$.

Conventional eucalyptus (hybrid: Eucalyptus urophylla x Eucalyptus grandis) bleached kraft pulp was used as a commercial standard feedstock for comparisons.

\section{Chemical characterization of fibers}

The percentage of holocellulose (cellulose + hemicelluloses) of the bamboo raw fiber, unrefined and refined bamboo pulps was determined. ${ }^{49}$ The contents of alpha-cellulose and lignin (insoluble in acid) were estimated. ${ }^{50-51}$ The content of hemicelluloses was calculated from the difference between the values of holocellulose and alphacellulose. The contents of $\operatorname{ash}^{52}$ and extractives ${ }^{53}$ were also calculated.

The contents of cellulose ${ }^{55}$ hemicelluloses and lignin $^{56}$ of the jute fibers were determined (using extractive-free samples). Hemicelluloses content was calculated as the difference of holocellulose and cellulose contents. Extractives ${ }^{57}$ and ash content ${ }^{58}$ were also determined.

Chemical determination of the eucalyptus pulp composition was performed following the standard procedures for cellulose, ${ }^{50}$ hemicelluloses, ${ }^{59}$ lignin, ${ }^{60}$ extractives $^{61}$ and ash. ${ }^{62}$

\section{Production of micro/nanofibrils}

Bamboo pulps, jute fibers and eucalyptus pulp were soaked in water $(1 \% \mathrm{w} / \mathrm{w})$ for at least $24 \mathrm{~h}$, and dispersed by stirring for $15 \mathrm{~min}$ before performing mechanical defibrillation. Each suspension was defibrillated using a SuperMasscolloider grinder (Masuko Sangyo Co., Ltd.) at $1500 \mathrm{rpm}^{46-47}$ with 30 passages to obtain the cellulose micro/nanofibrils, as represented in Figure 1.

\section{Transmission electron microscopy (TEM) of micro/nanofibrils}

Micro/nanofibrils were viewed by a FEI Tecnai 12 transmission electron microscope (TEM) operated at $120 \mathrm{kV}$. The samples that consisted of the diluted micro/nanofibril suspension were prepared by adding uranyl acetate as staining agent and thoroughly mixing. A drop of the suspension was deposited on a formvar/carbon coated 400 mesh copper grid, and dried before viewing by TEM. The average diameter of the micro/nanofibrils was determined by digital image analyses (ImageJ 1.48v, National Institutes of Health, USA) of the TEM micrographs, using only representative images of each treatment condition. A minimum of 500 measurements was collected for data analysis.

\section{X-ray diffraction (XRD) of micro/nanofibrils}

XRD patterns of the micro/nanofibril sheets were determined on a Philip PW3710 X-ray diffractometer using, $\mathrm{Cu}-\mathrm{K} \alpha$ radiation. Diffractograms were collected at a voltage of $40 \mathrm{kV}$ and $40 \mathrm{~mA}$ current, with a scan angle from $10^{\circ}$ to $40^{\circ}$ and a scan speed of $2^{\circ} / \mathrm{min}$. The crystalline fraction (CF) was determined to verify 
cellulose crystallinity of the fibers. CF determination was adapted from French, ${ }^{63}$ and Correia et al. ${ }^{64}$ (Eq. 1):

$\mathrm{CF}=\left(\mathrm{A}_{\mathrm{t}}-\mathrm{A}_{\mathrm{a}}\right) / \mathrm{A}_{\mathrm{t}}$

where CF is the crystalline fraction, $A_{t}$ and $A_{a}$ are the areas under the theoretical fitted pattern and the amorphous theoretical curve, respectively.

The Mercury 3.7 program $^{63,65}$ was used to produce the theoretical curves. The CIF (crystallographic information file) was obtained from complementary data in French, ${ }^{63}$ and edited for each different fiber. For this, monoclinic unit cell parameters ${ }^{66}$ were manipulated until the theoretical patterns reached the best fitting to the experimental curves, in accordance with the modern nomenclature (c as the fiber axis). ${ }^{63}$ Since cellulose $\mathrm{I} \beta$, with reflection peaks corresponding to (1-10), (110), (200) and (004) planes, is the most abundant cellulose polymorph occurring in nature for higher plants, ${ }^{67}$ its pattern was chosen to be used in the simulation. For the amorphous halo, cellulose II was used with peak width at half maximum height (pwhm) $=9,{ }^{67}$ and a correction factor to fit to the experimental curves. For comparison, Segal's crystalline index (CI) was also calculated according to Segal et al. ${ }^{68}$

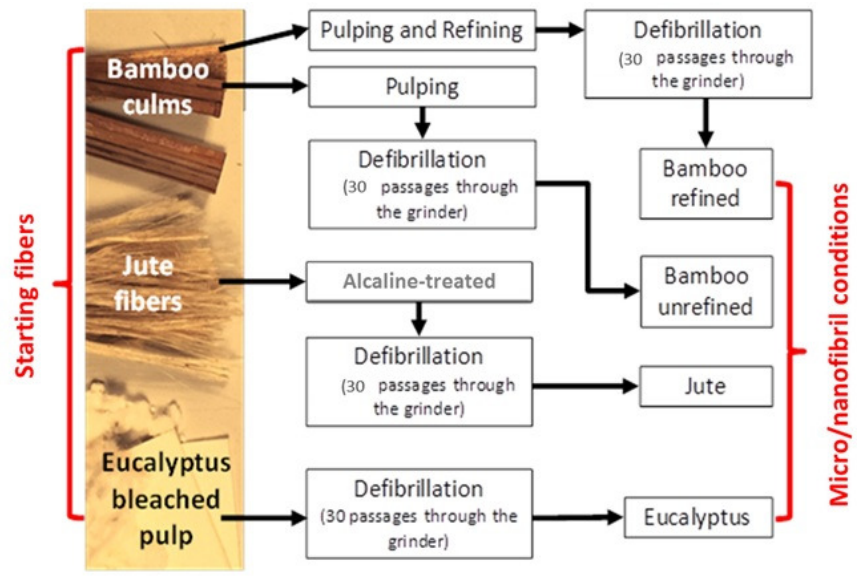

Figure 1: Illustrative scheme of the various processes used to obtain micro/nanofibrils

After the fitting process, all measurements for crystallite size and number of cellulose chains were carried out only on the theoretical curves. Crystallite size was determined by the Scherrer equation (Eq. 2), as described by Langford and Wilson: ${ }^{69}$

$\mathrm{D}=(\mathrm{K} \lambda) /(\beta \cos \theta)$

where $\mathrm{D}$ is the size perpendicular to the lattice plane (200); $\mathrm{K}$ is the Scherrer constant that depends on the crystal shape $(\mathrm{K}=0.9$, for cellulose); $\lambda$ is the wavelength of the incident X-ray (1.54056 $\AA$, for copper); $\theta$ is the Bragg angle corresponding to (200) plane; and $\beta$ the pwhm, in radians, of the (200) diffraction.

In order to find the number of cellulose chains (n) perpendicular to (200), D is divided by 4 angstroms, which are the width of cellulose chains. ${ }^{70}$ However, to determine the number of cellulose chains in the whole crystallite, Equation 3, proposed by Ballesteros et al., is needed:

$$
N=\left(\text { rounddown }\left(1+\left(\frac{n}{2}\right)\right), 0\right)^{2}
$$

The number of cellulose chains in the whole crystallite $(\mathrm{N})$ is related to the equation above, which is the square of the value rounded down to the integer of half of the number of cellulose chains (n) perpendicular to the plane (200) plus one.

\section{Attenuated total reflectance Fourier-transform infrared (ATR-FTIR) spectroscopy of micro/nanofibrils}

The samples were subjected to FTIR spectroscopy using a Thermo Scientific spectrometer equipped with the Smart iTX accessory, with a monolithic diamond ATR crystal attachment. Scanning was conducted from 3900 to $700 \mathrm{~cm}^{-1}$ with 16 scans averaged for each spectrum, at a resolution of $4 \mathrm{~cm}^{-1}$. Prior to the measurement, the samples were oven dried at $80{ }^{\circ} \mathrm{C}$ for 24 h. A commercial microcrystalline cellulose sample was used as a crystalline standard (CI 90\%), and amorphous cellulose obtained by ball milling was used as an amorphous standard.

\section{Thermogravimetry of micro/nanofibrils}

Thermogravimetric analysis (TGA) of the micro/nanofibrils was performed using a Perkin Elmer Pyris 1 TGA instrument. The samples ( 6 mg dry basis) were heated in a Pt crucible from 50 to $550{ }^{\circ} \mathrm{C}$, in synthetic air flowing at $60 \mathrm{~mL} / \mathrm{min}$, at a heating rate of $10^{\circ} \mathrm{C} / \mathrm{min}$. Critical weight loss temperatures $\left(\mathrm{T}_{\text {onset }}\right)$ were obtained from the onset points of the TGA 
curves, and this was represented by the intersection of the extrapolated line extended with the same slope from the beginning of the thermal event, with the tangent of the curve in the thermal event. ${ }^{22}$

\section{Preparation of micro/nanofibril sheets}

Cellulose micro/nanofibril sheets were prepared with defibrillated micro/nanofibrils from different fiber sources (Fig. 2). The sheets were formed by dewatering micro/nanofibril suspensions, followed by compression $(3.1 \mathrm{MPa})$ and oven drying $\left(80{ }^{\circ} \mathrm{C}\right)$ under compression between blotting papers. The resultant flat and dried cellulose discs were cut into $63.4 \mathrm{~mm}$ long $\mathrm{x}$ $12.7 \mathrm{~mm}$ wide $\mathrm{x} 1.5 \mathrm{~mm}$ thick specimens for mechanical and physical tests.

\section{Mechanical properties of micro/nanofibril sheets}

Flexural properties of the cellulose sheets were determined, ${ }^{72}$ with specimens cut from the flat sheets (63.5 mm long x $12 \mathrm{~mm}$ wide $\mathrm{x} 1.5 \mathrm{~mm}$ thick). Flexural strength, elastic modulus (MOE) and energy to break of the specimens were determined in the laboratory $\left(\sim 23{ }^{\circ} \mathrm{C}\right.$ and $\left.\mathrm{RH} \sim 65 \%\right)$ using an Instron (Canton, MA) 5500R universal testing system, equipped with a $1 \mathrm{kN}$ load cell and operated at an extension rate of $25.4 \mathrm{~mm} / \mathrm{min}$. For the three-point flexural test, the gauge length used was $27 \mathrm{~mm}$, and the crosshead speed was set to $2 \mathrm{~mm} / \mathrm{min}$. All the specimens were oven dried at $80{ }^{\circ} \mathrm{C}$ for at least $12 \mathrm{~h}$ before testing and 5 to 10 specimens were tested for each condition.

\section{Scanning electron microscopy (SEM) of the fracture surface of micro/nanofibril sheets}

The failure region (cross-section) of the samples following the bending test was analyzed by a Hitachi S-4700 field emission scanning electron microscope (FESEM). The samples were mounted on a specimen stub, using double adhesive coated carbon tabs (Ted Pella). The samples were coated with gold-palladium in a Denton Desk II sputter coating unit (Denton Vacuum). Finally, the samples were viewed by FESEM. Images were captured at $2650 \times 1920$ pixel resolution.

\section{Physical properties of micro/nanofibril sheets}

Bulk density $\left(\rho_{\text {bulk }}\right)$ was determined from the measurements of volume and weight of oven-dried (48 $\mathrm{h}$ at $60{ }^{\circ} \mathrm{C}$ ) samples. True density $\left(\rho_{\text {true }}\right)$ of the fibers was also determined in order to monitor the influence of the micro/nanofibril conditions on the fiber structure. Ten values of true density for each treatment were measured using a gas (Helium) pycnometer (AccuPyc II 1340 Series Pycnometer, Micromeritics Instrument Co.). Apparent porosity (AP) was obtained directly based on the definition (Eq. 4):

$\mathrm{AP}=1-\left(\rho_{\text {bulk }} / \rho_{\text {true }}\right)$

where $\rho_{\text {bulk }}$ is bulk density, and $\rho_{\text {true }}$ is true density, as determined before.

Three $10 \mathrm{~mm} \times 10 \mathrm{~mm} \times 1.5 \mathrm{~mm}$ samples of each formulation were dried for $48 \mathrm{~h}$ at $60{ }^{\circ} \mathrm{C}$, weighed, and placed in hermetically closed containers with $97 \pm 2 \%$ of relative humidity (RH) and $20 \pm 2{ }^{\circ} \mathrm{C}$, using a saturated potassium sulfate solution. ${ }^{73}$ The moisture adsorbed by the samples over time was determined by weight gain (0.0001 g precision) from measurements made at successive intervals until a constant weight was achieved. The amount of moisture adsorbed by the samples was calculated. ${ }^{74,75}$ Each data point represents an average of three samples.

The resistance of the sheets to water immersion was determined using $10 \mathrm{~mm} \times 10 \mathrm{~mm} \times 1.5 \mathrm{~mm}$ test specimens (three replicates). This test is important to verify the water resistance of the cellulose sheets when exposed to limiting conditions. The tests were performed by immersing the specimens in a vessel containing $30 \mathrm{~mL}$ of distilled water and stirring at 300 $\mathrm{rpm}$ for $48 \mathrm{~h}$ at room temperature. The resultant suspensions were filtered, and the residues were dried at $105{ }^{\circ} \mathrm{C}$ for $24 \mathrm{~h}$. After weighing, the amount of nonsolubilized material was determined. The solubility of the specimens was expressed as percentage of mass solubilized in relation to the initial mass. ${ }^{76}$

\section{RESULTS AND DISCUSSION Chemical composition of fibers}

The chemical composition of the fibers is presented in Table 1. Pulping decreased the relative lignin and hemicelluloses contents, and increased the relative cellulose content of the bamboo fibers. Refining the bamboo fibers had little impact on chemical composition. The alkaline treatment increased the relative cellulose content of the jute fibers, while it decreased the hemicelluloses content (Table 1). Lignin content remained almost unchanged for the alkaline pretreated fibers, but was significantly lower in the bleached eucalyptus pulp. This was due to the degradation and dissolution of lignin during kraft pulping and the removal of residual lignin during pulp bleaching. 


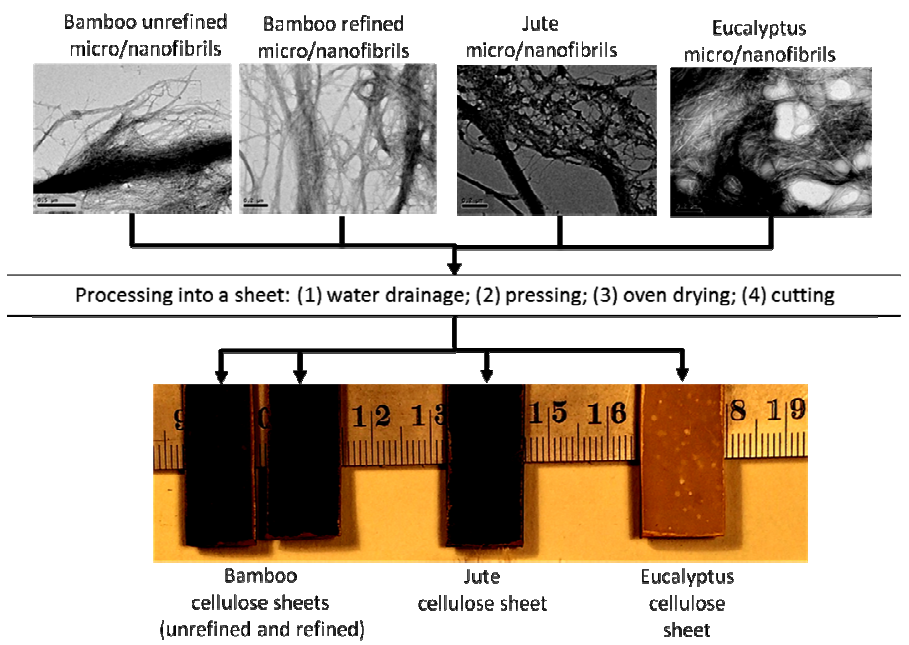

Figure 2: Illustrative scheme of the various preparation processes of the sheets

When hemicelluloses and lignin are dissolved from the fiber cell wall during the pulping process, it is easier to release the individual fibers, and consequently the cellulose micro/nanofibrils. However, as a result of the high temperature, pressure and time of exposition during the pulping process, the cellulose chains may also become degraded. The hemicelluloses turn the fiber cell wall easier to be delaminated and depolymerized. ${ }^{1}$ They also may act as inhibitors of the coalescence of micro/nanofibrils during drying and can contribute to the enhancement of mechanical properties in composites. ${ }^{77}$ The presence of lignin can significantly increase film tensile index and elastic modulus. ${ }^{78}$

\section{Morphology of micro/nanofibrils}

The starting raw jute presents individual fibers with average diameter of around $16 \pm 3 \mu \mathrm{m}$, with individual values in the range between $6 \mu \mathrm{m}$ (minimum) and $25 \mu \mathrm{m}$ (maximum), and fiber length of $2.1 \pm 0.3 \mathrm{~mm}$. These values are lower than those reported elsewhere. ${ }^{79-81}$ The average values of length and diameter of the bamboo raw fiber were around $2.3 \mathrm{~mm}$ and $13.9 \mu \mathrm{m}$, respectively, which are very similar to those found by Chew et al. ${ }^{82}$

The eucalyptus fibers presented average length and diameter of $0.7 \pm 0.3 \mathrm{~mm}$ and $17 \pm 4 \mu \mathrm{m}$, respectively, which are in the same range found by Belini et al. ${ }^{83}$ and Brisola and Demarco. ${ }^{84}$ Normally, jute and bamboo are considered long fibers, while eucalyptus is considered a short fiber.

The typical morphologies of the micro/nanofibrils from the different starting materials are presented in Figure 3. The alkalinetreated jute fibers showed suspensions with a higher degree of nanofibrillation (Fig. 3a). Also, alkaline-treated micro/nanofibrils seem less degraded than those subjected to other pretreatments (Fig. 3a). The cellulose nanocrystal silhouette is more evident when using high magnification (details in Fig. 3).

Table 1

Chemical composition of bamboo pulps (unrefined and refined), raw jute, alkaline-treated jute fibers and eucalyptus bleached pulp

\begin{tabular}{lccccc}
\hline Fiber conditions & $\begin{array}{c}\text { Extractives, } \\
\text { wt\% }\end{array}$ & $\begin{array}{c}\text { Lignin, } \\
\text { wt } \%\end{array}$ & $\begin{array}{c}\text { Cellulose, } \\
\text { wt } \%\end{array}$ & $\begin{array}{c}\text { Hemicelluloses, } \\
\text { wt\%, }\end{array}$ & $\begin{array}{c}\text { Ash, } \\
\text { wt } \%\end{array}$ \\
\hline Bamboo - raw* & 13.2 & 18.1 & 39.7 & 26.7 & 2.2 \\
Bamboo - unrefined pulp & 7.1 & 6.7 & 74.3 & 10.0 & 2.0 \\
Bamboo - refined pulp & 7.1 & 6.6 & 74.0 & 10.5 & 1.9 \\
Jute - raw* & 1.8 & 11.9 & 53.2 & 32.2 & 0.9 \\
Jute - alkaline-treated & - & 11.8 & 77.2 & 10.6 & 0.4 \\
Eucalyptus pulp & 0.1 & 0.1 & 85.3 & 13.9 & 0.6 \\
\hline
\end{tabular}

*before pulping or chemical pretreatments 

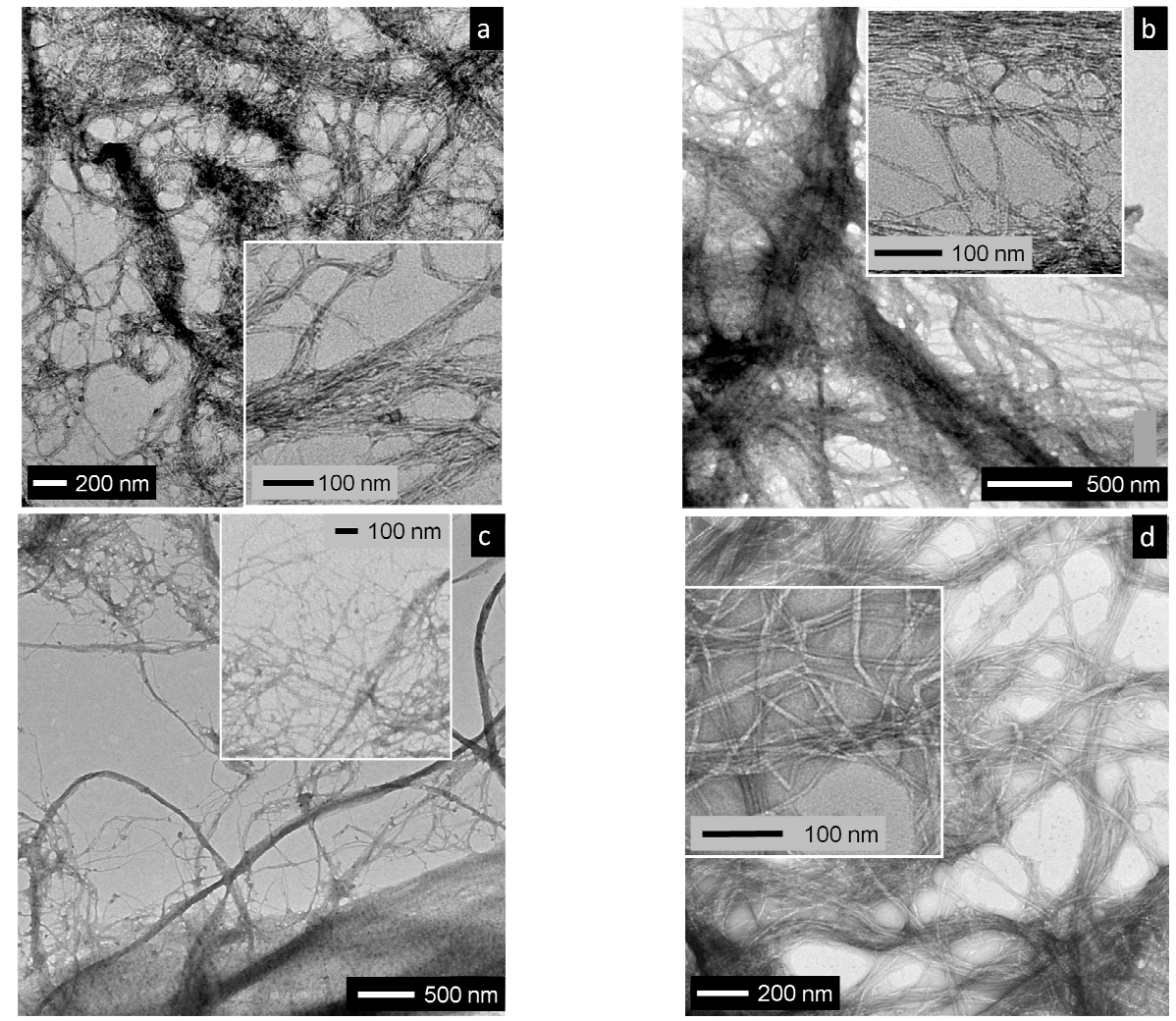

Figure 3: Typical TEM images of micro/nanofibrils obtained by different processes: a) bamboo unrefined;

b) bamboo refined; c) jute; and d) eucalyptus pulp (high magnifications make the crystals more visible)

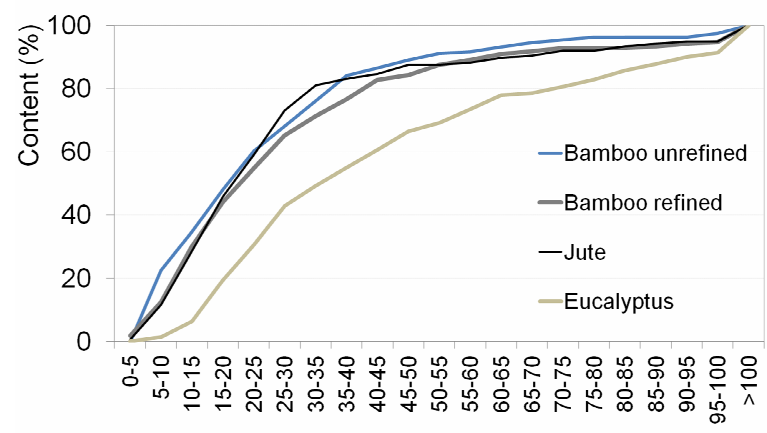

Diameter $(\mathrm{nm})$

Figure 4: Diameter distribution of e micro/nanofibrils from different plant fibers

As shown in the previous section, the alkalinetreated fibers still have some lignin content in the cell wall, but this fact has not hindered the process of defibrillation. Figure 4 depicts the diameter distribution of the micro/nanofibrils determined using the TEM images. Almost $80 \%$ of bamboo and jute nanofibril diameters were lower than $40 \mathrm{~nm}$. For eucalyptus, just $55 \%$ were lower than $40 \mathrm{~nm}$, which is probably because of the incomplete defibrillation. The average nanofibril diameters in the suspensions of unrefined bamboo, refined bamboo, jute and eucalyptus micro/nanofibrils were $35 \pm 35 \mathrm{~nm}$, $33 \pm 36 \mathrm{~nm}, 31 \pm 33 \mathrm{~nm}$, and $50 \pm 41 \mathrm{~nm}$, respectively. Qing et al. ${ }^{85}$ obtained cellulose micro/nanofibrils with lengths in the range of 9$170 \mathrm{~nm}$ and average diameter of $48 \pm 45 \mathrm{~nm}$. Lavoine et al. ${ }^{2}$ obtained microfibrillated cellulose with diameters ranging from 20 to $50 \mathrm{~nm}$. Despite the presence of lignin in the bamboo pulps and 
alkaline-treated jute fibers, the cellulose micro/nanofibers were obtained for all the conditions. A large content of fibrils in the nanoscale range (1 to $100 \mathrm{~nm}$ ) was observed for the bamboo and jute fiber suspensions.

\section{Microstructure of micro/nanofibril sheets}

Scanning electron microscopy provides information on the microstructure of cellulose sheets, and permits the observation of the interaction and dispersion of the micro/nanofibrils in the sheets. Micrographs of the fracture surface of the sheets are shown in Figure 5. In the cases when the micro/nanofibril suspension presents some agglomeration of nanofibrils or large pieces of non-defibrillated fibers, it may cause porosity, voids or cracks in the microstructure of the cellulose sheets.

The fracture surface of the bamboo and jute specimens (Fig. 5a-c) appears homogeneous, compact and without visible voids and large nondefibrillated fibers. The fracture surfaces of the micro/nanofibril sheets show that large pieces of

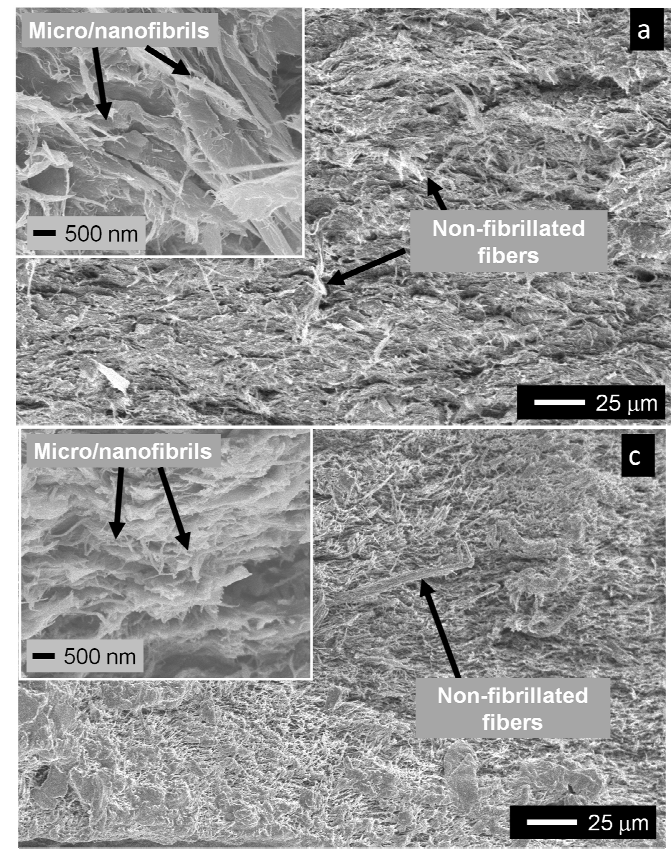

poorly defibrillated fibers were pulled out from the cross-section. These fiber bundles acted as stress concentrators, and as a result, failure of the specimens occurred at the interface of this weakly inter-penetrated network structure (IPN).

\section{Crystallinity of micro/nanofibrils}

X-ray diffraction patterns (XRD) of the micro/nanofibrils are shown in Figure 6. The highest intensity of the allomorph is present in the region between $2 \theta=18^{\circ}$ and $2 \theta=22^{\circ}$, and also according to the disposition of the diffraction peaks, it indicates the presence of cellulose I $\beta$, which is the polymorph that mostly occurs naturally in higher plants. ${ }^{67}$ All the fiber samples exhibited a sharp peak at $2 \theta=22.7^{\circ}$, which is assigned to the (200) lattice plane of cellulose I. The presence of amorphous and crystalline regions indicates a semi-crystalline material. The two overlapping weaker diffraction peaks at $2 \theta=15.4^{\circ}$ and $2 \theta=16.3^{\circ}$ are assigned to the (1-10) and (110) lattice planes of cellulose I. ${ }^{86-87}$

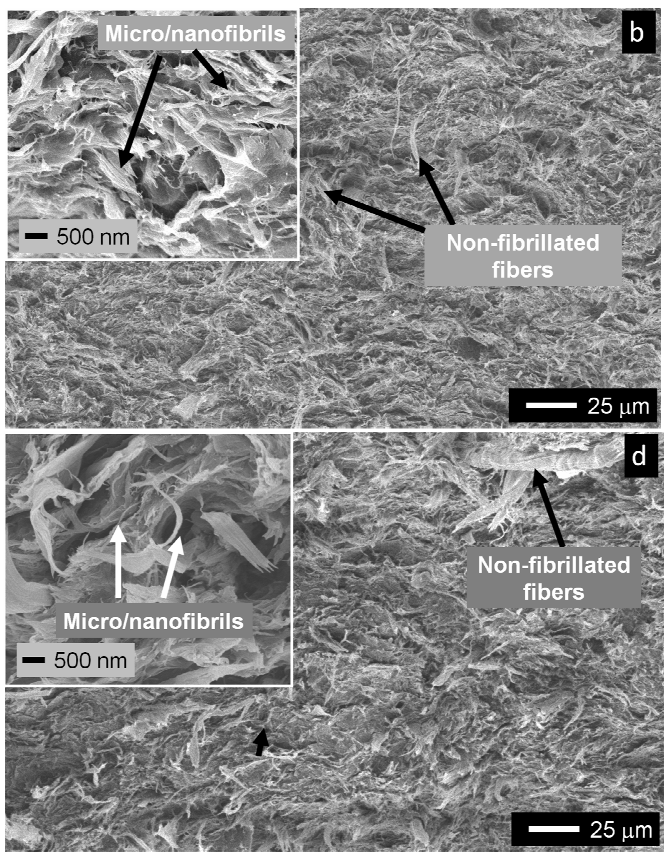

Figure 5: Typical FESEM images of the fracture surface of sheets with micro/nanofibrils from different starting fibers: a) bamboo unrefined; b) bamboo refined; c) jute; and d) eucalyptus pulp 

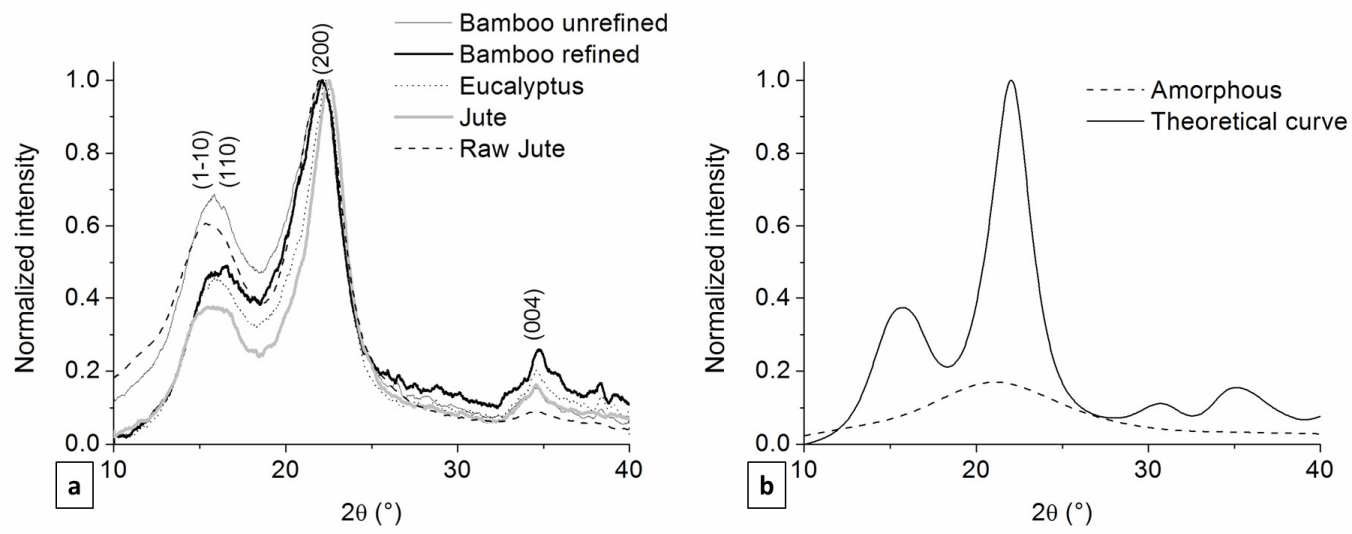

Figure 6: a) Typical X-ray patterns of the micro/nanofibrils from unrefined bamboo, refined bamboo, jute and eucalyptus pulp (raw jute fiber (before defibrillation) is also presented for comparison); b) example of theoretical modeled curves generated by the Mercury program to fit typical X-ray patterns for jute

Table 2

Crystalline parameters of the different cellulose materials

\begin{tabular}{lcccc}
\hline Cellulose material & $\begin{array}{c}\text { Crystalline } \\
\text { fraction }-\mathrm{CF} \\
(\%)\end{array}$ & $\begin{array}{c}\text { Segal's } \\
\text { crystallinity } \\
\text { index }- \text { CI (\%) }\end{array}$ & $\begin{array}{c}\text { Crystallite } \\
\text { size }(\AA)\end{array}$ & $\begin{array}{c}\text { Cellulose } \\
\text { chains per } \\
\text { crystallite }\end{array}$ \\
\hline Bamboo unrefined (nanofibrils) & 64 & 48 & 64 & 81 \\
Bamboo refined (nanofibrils) & 67 & 59 & 74 & 100 \\
Jute (nanofibrils) & 68 & 67 & 106 & 196 \\
Eucalyptus (nanofibrils) & 65 & 65 & 85 & 144 \\
Raw jute (starting fiber)* & 66 & 61 & 80 & 121 \\
\hline
\end{tabular}

*before defibrillation

Cellulose I is a structure comprising repeating $\beta$ - $(1 \rightarrow 4)$-D-glucopyranose units with building blocks of parallel glucan chains. ${ }^{88}$ The overlapping of these (1-10) and (110) planes results in a single broad peak, due to the large peak width at half maximum height (pwhm) ${ }^{89}$ In this sense, an inverse relation of pwhm with the crystallite size of the cellulose micro/nanofibrils, as defined in Scherrer's equation, was found for all the sample patterns (Fig. 6a). Micro/nanofibrils from unrefined bamboo and jute showed the lowest and highest values for crystallite size, respectively. For the unrefined bamboo sample, this behavior may indicate that there was an increase in the distribution value of the interlamellar distances, consistent with a less ordered crystallite structure. It indicates a certain disorder in the crystal lattice and a smaller amount of crystalline phase for bamboo, probably due to the process of defibrillation, which affected the crystalline region more than the amorphous region. These results confirm that the jute samples contain a higher number of highly organized cellulose chains (Table 2) in the cellulose crystallite. This can lead to higher hydrogen bondings among neighboring cellulose chains, resulting in a more packed cellulose structure, as also confirmed by their higher crystallinity (CF and CI) according to the data presented in Table $2 .^{90}$ This behavior was also observed by Nam et $a l .{ }^{67}$ and Oliveira and Driemeier. ${ }^{91}$

Jute micro/nanofibrils presented a higher crystalline fraction $(\mathrm{CF})$ due to its sharp peak (200). ${ }^{92}$ A minor variation in the position of the cellulose I (200) peak for jute fiber (Fig. 6) was attributed to differences in sample geometry. The jute micro/nanofibrils show more distinct separation of the peaks at $2 \theta=15.4^{\circ}$ and $2 \theta=16.3^{\circ}$, with a little dislocation of the (110) peak to higher values. The separation of these peaks (1-10 and 110) was also observed by Chan et al., ${ }^{93}$ with increasing crystallinity of the fibers. The peak at around $2 \theta=35^{\circ}$ corresponding to (004) lattice planes is reported elsewhere, ${ }^{63}$ as a combination of several reflections due to the lack of preferred orientation of the cellulose crystals in the sample holder.

Micro/nanofibrils from unrefined bamboo pulps presented lower CF than the other raw materials (Table 2), it is probably because of the 
relatively large content of extractives identified in their starting fibers (Table 1). Refined bamboo pulp has suffered high mechanical shear forces during previous refining, which probably partially modified the crystal structures of the cellulose micro/nanofibrils. The subsequent drying for sample preparation has probably caused its reorganization and increased $\mathrm{CF}$ and $\mathrm{CI}$ in relation to the unrefined bamboo.

Jute micro/nanofibrils exhibited higher CF than the raw jute because of the dissolution and breaking of amorphous regions during the pretreatment and defibrillation process respectively. It is important to emphasize that this apparent increase in CF and CI was most likely due to the removal of amorphous domains (hemicelluloses, lignin and some amorphous cellulose) and not to an increase in order of the less ordered region.

Bleached eucalyptus pulp also generates more crystalline micro/nanofibrils than the bamboo samples because the starting fiber was alkali treated during the kraft pulping and bleaching steps. It is expected that alkali treatment would preferentially attack the amorphous regions of the fibers, depolymerizing the terminal and glycoside units of lower molecular mass.

The calculated $\mathrm{CF}$ values are probably somewhat lower than true values, because the presence of those small peaks in the crystal structure of the cellulose I diffraction pattern ${ }^{63}$ was not considered in the fitting presented in Figure 6a. Also, the fitting did not predict the peaks overlap, which may have been caused by higher pwhm values, thus increasing the minimum intensity in the region related to the amorphous fractions between $2 \theta=18^{\circ}$ and $22^{\circ}$. These effects that may arise from those calculations was not compensated here. For most of the fibers, the $\mathrm{CF}$ values were higher than Segal's crystallinity index (CI) (Table 2). Even though CI showed similar tendencies to $\mathrm{CF}$, changes in the peaks other than that related to (200) plane does not account for crystallinity. CI values were lower than $\mathrm{CF}$ values because the results are related to the whole sample (cellulose and other amorphous components of the fiber) and not just for the cellulose portion (as used for $\mathrm{CF})$.

\section{ATR-FTIR spectroscopy of micro/nanofibril sheets}

ATR-FTIR spectroscopy evidenced the capacity of different absorption bands to characterize the crystal and amorphous structures of the different cellulose conditions (Fig. 7), and corroborate the XRD results of the previous section. The decrease in the crystalline organization (and/or content) leads to a significant simplification of the spectra through reduction in intensity or even disappearance of the bands characteristic of the crystalline domains. The broad band in the $3100-3600 \mathrm{~cm}^{-1}$ range is due to the $\mathrm{OH}$-stretching vibration, which gives considerable information concerning the hydrogen bonds in the fibers or micro/nanofibrils. Normally, the peaks characteristic of hydrogen bonds from the spectra of amorphous celluloses became smoother and with lower intensity, compared to the more crystalline condition, which can be correlated with the scission of the intraand intermolecular hydrogen bonds. Additionally, for more amorphous samples (that is the case of unrefined bamboo), the peak for hydrogen bonds is shifted to higher wavenumber values, as also reported by Ciolacu et al. ${ }^{94}$ According to these authors, the presence of the amorphous fraction can be further confirmed by the decrease in the intensity of the band at $2900 \mathrm{~cm}^{-1}$, as also observed in the present work, which corresponds to the $\mathrm{C}-\mathrm{H}$ stretching vibration. ${ }^{95}$ The peaks at $1735 \mathrm{~cm}^{-1}$ for jute represents vibrations of acetyl and uronic ester groups of hemicelluloses or ester linkage of carboxylic groups of the ferulic and pcoumaric acids of lignin. ${ }^{96-98}$

Finally, the bands at $1430 \mathrm{~cm}^{-1}$ and $1370 \mathrm{~cm}^{-1}$, assigned to a symmetric $\mathrm{CH}_{2}$ bending vibration of the crystalline domains, are lower for the samples with a lower crystallinity index. The peaks at around $1155 \mathrm{~cm}^{-1}$ (referred to $\mathrm{C}-\mathrm{O}$ vibration), $1105 \mathrm{~cm}^{-1}$ (related to ring asymmetric valence), and $1000 \mathrm{~cm}^{-1}$ (related to $\mathrm{C}-\mathrm{O}$ valence vibration at $\mathrm{C}(6)$ ) are much lower for the less amorphous samples and increased for those with higher crystallinity.

\section{Thermogravimetry (TGA) of micro/nanofibrils}

The thermal properties of the micro/nanofibrils are an important parameter for identifying the different applications for these cellulose nanostructures, such as thermal sensitive papers, cosmetics, processing additives, disposable products etc. Thermal analysis (TGA) of the samples showed two thermal degradation stages (Fig. 8), indicating the presence of different components that decompose at different temperatures. The jute micro/nanofibrils were the first to lose mass at low temperature (up to 150 
${ }^{\circ} \mathrm{C}$ ), probably because they still had somewhat high moisture content (around 5-6\%), compared to their counterparts (around 2-3\%). The first stage of thermal decomposition occurred at temperatures of $150-350{ }^{\circ} \mathrm{C}$, with a weight loss of around $60 \%$ for all the micro/nanofibrils samples. The onset degradation temperature $\left(\mathrm{T}_{\text {onset }}\right)$ was very similar for all the micro/nanofibrils (from $316{ }^{\circ} \mathrm{C}$ to $323{ }^{\circ} \mathrm{C}$ ) and the little differences between the fiber sources corroborate the results of Segal's crystallinity index (Table 2). The $\mathrm{T}_{\text {onset }}$ values is in the temperature range corresponding to the weight loss of hemicelluloses $\left(225-325^{\circ} \mathrm{C}\right)$, residual lignin $\left(250-500{ }^{\circ} \mathrm{C}\right)$ and cellulose $(305-$ $\left.375^{\circ} \mathrm{C}\right) .{ }^{99,100}$ The second thermal degradation stage occurred between 350 and $500{ }^{\circ} \mathrm{C}$. Jute micro/nanofibrils degraded earlier than the other micro/nanofibrils in the second stage, probably because of the higher content of residual lignin (as presented in Table 1 for alkaline-treated jute). No thermal event was observed at temperatures higher than $500{ }^{\circ} \mathrm{C}$ (Fig. 8).

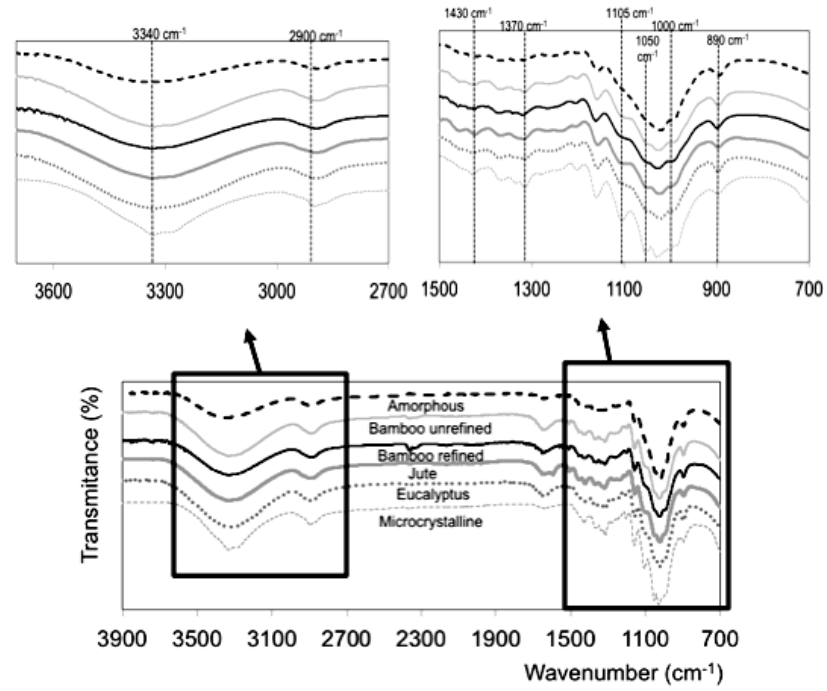

Figure 7: Typical ATR-FTIR spectra of the micro/nanofibrils from different starting fibers (amorphous cellulose obtained by ball milling treatment was used as an amorphous standard, while commercial microcrystalline cellulose was used as a crystalline standard (CI 90\%))

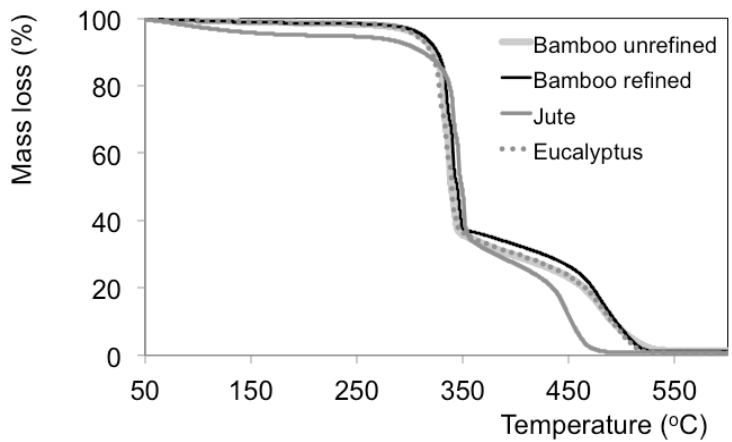

Figure 8: Typical TGA thermograms of the micro/nanofibrils from different plant fibers; onset degradation temperatures $\left(\mathrm{T}_{\text {onset }}\right)$ : bamboo unrefined $=317^{\circ} \mathrm{C}$; bamboo refined $=320^{\circ} \mathrm{C}$; jute $=323{ }^{\circ} \mathrm{C}$; and eucalyptus $=316{ }^{\circ} \mathrm{C}$

\section{Mechanical performance of micro/nanofibril} sheets

The flexural properties of the micro/nanofibril sheets are shown in Table 3. The micro/nanofibril sheets formed from jute and bamboo micro/nanofibrils presented high flexural strength,
MOE and energy to break, than those from eucalyptus. Eucalyptus has the highest cellulose content, and the CI is almost the same as that of jute micro/nanofibrils. The diameter of the produced eucalyptus micro/nanofibrils is higher, compared to that of jute and bamboo, which 
indicates that defibrillation might be incomplete, resulting in poor IPN, as discussed above, and probably this is the reason for the lower strength. Then, there are many more free hydrogen groups available on the surface of the micro/nanofibrils than on the surface of the pulp fibers, which greatly increases the bonding potential between the fibrillated elements in the micro/nanofibril sheet.

The higher number of micro/nanofibrils increased the energy to break point of the cellulose sheets. The energy to break is the amount of hydrogen bonds at the break point, which could be just the consequence of a tiny spot in the specimen (a local effect) or the result of a lower number of interconnected nanofibrils. A higher number of hydrogen bonds between micro/nanofibrils improves the cohesion in the sheets upon drying and leads to lower thickness of the sheets. The mechanical properties of the sheets depend on the surface area of the micro/nanofibrils, but the chemical composition of the micro/nanofibril suspensions may also have an influence. Normally, high content of lignin means less fibrillated fibers. Hemicelluloses play an important role in the adhesion between cellulose micro/nanofibrils, which contributes to mechanical strength. ${ }^{77}$ The eucalyptus micro/nanofibrils sheets had lower mechanical properties and also lower lignin content. The presence of lignin significantly increased flexural strength and elastic modulus of similar microfibril sheets. $^{78}$

For the jute micro/nanofibril sheets that had been subjected to an advanced defibrillation process, the large surface area of the smaller nanofibrils permitted greater flexural strength and energy to break (Table 2). This is also because of the improved distribution of the nanofibrils that led to more efficient packaging and more compact structure of the cellulose sheet. When the micro/nanofibril suspension presents some agglomeration of nanofibrils or large pieces of non-defibrillated fibers, it may cause large pores, fissures and/or cracks in the microstructure of the cellulose sheets.

As a comparison, the values of flexural strength obtained in the present work for the micro/nanofibril sheets are much higher than those of polylactic acid - PLA (70 MPa), poly-Llactic acid - L-PLA (119 MPa), poly (hydroxy butyrate-co-valerate) - PHB (43 $\mathrm{MPa})$, polystyrene - PS (80 MPa), polyvinyl chloride PVC (90 MPa) and polypropylene - PP (49 $\mathrm{MPa}){ }^{101-103}$ Therefore, the mechanical properties of these micro/nanofibril sheets are comparable to those of petroleum-based plastics and thus, depending on the application, they can be considered as a possible substitute.

\section{Physical properties of micro/nanofibril sheets}

Table 3 presents the average values of density, porosity and disintegration in water of the micro/nanofibril sheets. Eucalyptus sheets presented lower values of bulk density and higher values of apparent porosity, which corroborates the results discussed in the previous sections. Moisture adsorption of the sheets was significantly influenced by the type of micro/nanofibrils (Fig.

Table 3

Average and standard deviation values of flexural properties of the micro/nanofibril sheets

\begin{tabular}{lccc}
\hline & $\begin{array}{c}\text { Flexural strength } \\
(\mathrm{MPa})\end{array}$ & $\begin{array}{c}\text { MOE } \\
(\mathrm{GPa})\end{array}$ & $\begin{array}{c}\text { Energy to break } \\
\text { point }\left(\mathrm{J} / \mathrm{m}^{2}\right)\end{array}$ \\
\hline Bamboo unrefined & $162 \pm 32$ & $12 \pm 3$ & $3.0 \pm 1.7$ \\
Bamboo refined & $164 \pm 29$ & $11 \pm 2$ & $3.8 \pm 0.8$ \\
Jute & $183 \pm 25$ & $11 \pm 2$ & $4.7 \pm 1.7$ \\
Eucalyptus & $97 \pm 19$ & $8 \pm 1$ & $1.7 \pm 0.5$ \\
\hline
\end{tabular}

The bamboo and jute micro/nanofibril sheets presented lower water adsorption than eucalyptus micro/nanofibril sheets, probably due to the higher number of bonds between the bamboo and jute micro/nanofibrils and to the higher content of extractives and lignin in those non-wood fibers (Table 1). It is well known that the number of free
$\mathrm{OH}$ groups in the cellulose is higher than that in the lignin, for example. Cellulose contains 3 $\mathrm{OH} / \mathrm{C}_{6}$, whereas lignin has $1-2$ free $\mathrm{OH}$ groups $/ \mathrm{C}_{9}{ }^{104}$ Based on this, it is obvious that unbleached micro/nanofibrils (bamboo and jute) dispose of lower surface energy, ${ }^{29,105}$ and probably negligible polar contribution when 
compared to bleached eucalyptus micro/nanofibrils. Furthermore, again the large pieces of non-defibrillated fibers, as enforced by the SEM observations of the cross-section of the fractured eucalyptus sheet (Fig. 5d), may lead to voids in the microstructure of the cellulose sheets, as already mentioned before.

Table 4

Average and standard deviation values of bulk density, true density, apparent porosity and water resistance of the micro/nanofibril sheets

\begin{tabular}{lcccc}
\hline & $\begin{array}{c}\text { Bulk density } \\
\left(\mathrm{g} / \mathrm{cm}^{3}\right)\end{array}$ & $\begin{array}{c}\text { True density } \\
\left(\mathrm{g} / \mathrm{cm}^{3}\right)\end{array}$ & $\begin{array}{c}\text { Apparent } \\
\text { porosity }(\%)\end{array}$ & $\begin{array}{c}\text { Water resistance } \\
(\%)\end{array}$ \\
\hline Bamboo unrefined & $1.22 \pm 0.09$ & $1.54 \pm 0.01$ & $20.7 \pm 5.0$ & $0.7 \pm 0.1$ \\
Bamboo refined & $1.31 \pm 0.07$ & $1.53 \pm 0.01$ & $14.7 \pm 3.8$ & $0.3 \pm 0.2$ \\
Jute & $1.23 \pm 0.03$ & $1.51 \pm 0.01$ & $18.6 \pm 1.6$ & $0.4 \pm 0.3$ \\
Eucalyptus & $1.19 \pm 0.01$ & $1.56 \pm 0.01$ & $23.3 \pm 0.3$ & $0.9 \pm 0.1$ \\
\hline
\end{tabular}
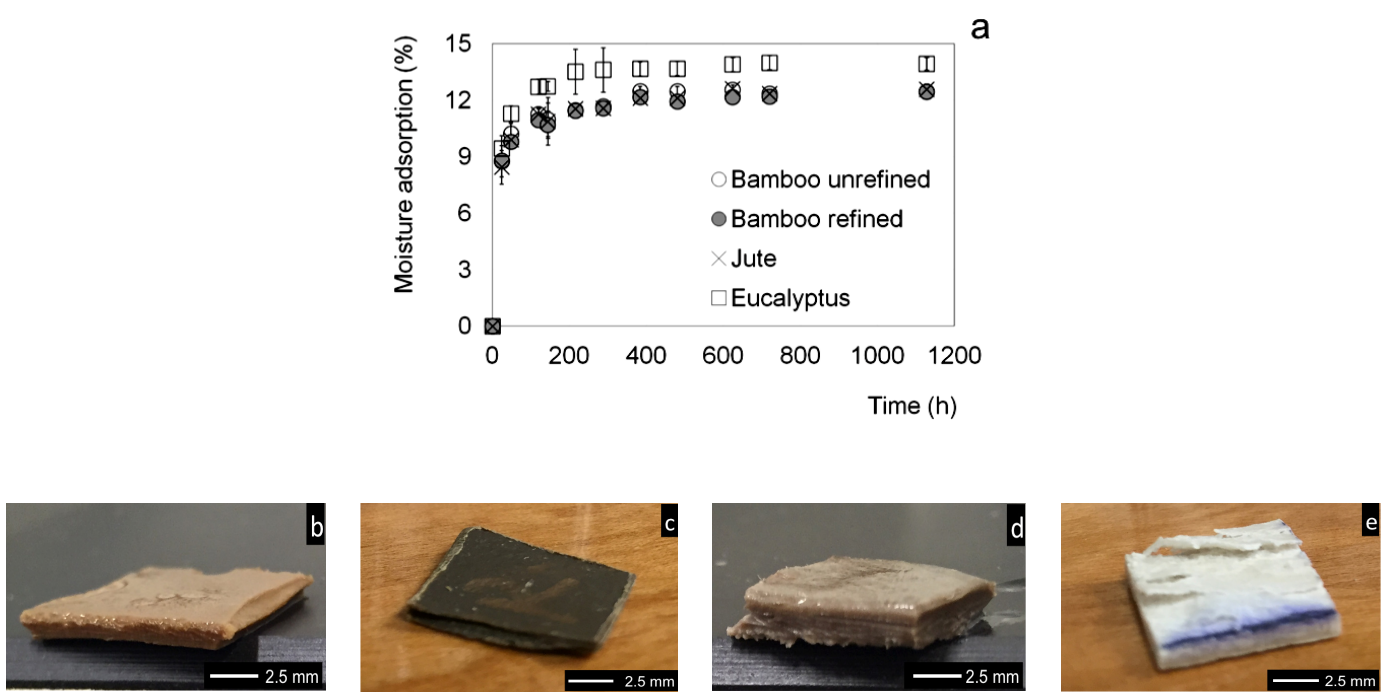

Figure 9: (a) Average and standard deviation values of moisture adsorption of the sheets with different micro/nanofibrils; Images of the micro/nanofibril sheets after $48 \mathrm{~h}$ of water immersion: (b) unrefined bamboo; (c) refined bamboo; (d) jute; and (e) eucalyptus

The eucalyptus micro/nanofibril sheets also presented higher resistance to water immersion (Table 4), presenting some swelling that caused high dimensional instability and fiber delamination (Fig. 9e) after $48 \mathrm{~h}$ of water immersion. The higher resistance of the eucalyptus sheet to water immersion $(0.9 \%)$ was the consequence of the larger diameter of the nanofibrillated particles, which reduced the percolated network, ${ }^{105}$ and increased the formation of pores and fissures in these sheets (Fig. 5d). The formation of fissures and pores occurred because of the insufficient amount of micro/nanofibrils bonded together in the eucalyptus sheets, in opposition to the very packed structure observed for the bamboo and jute sheets after $48 \mathrm{~h}$ of water immersion (Fig. 9bd).

\section{CONCLUSION}

Cellulose micro/nanofibrils were obtained from sustainable and fast-growing woody biomass fibers, with an average diameter between 30-50 $\mathrm{nm}$, and most in the nanoscale range (1 to 100 $\mathrm{nm})$. Jute micro/nanofibrils degraded to shorter fibrils more rapidly, compared to the other micro/nanofibrils, at higher temperatures, probably because of the higher content of lignin, resulting in brittleness. The changes in the crystalline organization in the fibrils were also supported by the XRD diffractograms and ATRFTIR spectra, with jute nanofibrils presenting higher crystalline fraction (CF) and crystallinity 
index $(\mathrm{CI})$ than their counterparts. Bamboo and jute micro/nanofibrils led to sheets with higher flexural strength (162 to $183 \mathrm{MPa}$ ), MOE (11 to $12 \mathrm{GPa}$ ) and energy to break ( 3 to $4.7 \mathrm{~J} / \mathrm{m}^{2}$ ) than those of the eucalyptus cellulose sheets. Eucalyptus micro/nanofibrils led to lower flexural performance of the sheets because they presented a large content of non-defibrillated fibers, which was probably caused by the incomplete defibrillation under the conditions used in the present work. Also, eucalyptus sheets presented higher apparent porosity, leading to higher water adsorption, swelling in water and delamination after $48 \mathrm{~h}$ of water immersion.

ACKNOWLEDGMENTS: For their financial support, the authors thank Coordenação de Aperfeiçoamento de Pessoal de Nível Superior (CAPES - process n. bex 14459/13-2), Conselho Nacional de Pesquisa e Desenvolvimento (CNPq - process n. 309796/2012-1; 484082/2013-2; 506506/2013-4), Fundação de Apoio a Pesquisa do Estado de Minas Gerais (Fapemig - process n. apq-02515-14), Brazil; University of Toronto, Canada; and United States Department of Agriculture (USDA), USA. Thanks are also due to Rede Brasileira de Compósitos e Nanocompósitos Lignocelulósicos (Religar), Graduate Program in Biomaterials Engineering (UFLA) and Graduate Program in Wood Science and Technology (UFLA), Brazil.

\section{REFERENCES}

1 D. Klemm, F. Kramer, S. Moritz, T. Lindström, M. Ankerfors et al., Angew. Chem. Int. Ed., 50, 5438 (2011), https://doi.org/10.1002/anie.201001273

2 N. Lavoine, I. Desloges, A. Dufresne and J. Bras, Carbohyd. Polym., 90, $735 \quad$ (2012), https://doi.org/10.1016/j.carbpol.2012.05.026

3 L. Bufalino, L. M. Mendes, G. H. D Tonoli, A. Rodrigues, A. Fonseca et al., Mater. Sci. Eng., 64, 1 (2014), https://iopscience.iop.org/article/10.1088/1757899X/64/1/012012

4 L. Bufalino, A. R. Sena Neto, G. H. D. Tonoli, A. S. Fonseca, T. G. Costa et al., Cellulose, 22, 3657 (2015), https://doi.org/10.1007/s10570-015-0771-3

5 L. Bufalino, G. H. D Tonoli, T. G. Costa, T. P. Protásio, A. R. Sena Neto et al., Key Eng. Mater., 668, 110 (2015).

6 E. Gicquel, C. Martin, J. G. Yanez and J. Bras, J. Mater. Sci., 52, 3048 (2016), DOI: 10.1007/s10853016-0589-x

7 M. Guimarães Jr., F. D. Teixeira and G. H. D.

Tonoli, Cellulose, 25, $1823 \quad$ (2018), https://doi.org/10.1007/s10570-018-1691-9
8 T. Arbatan, L. Zhang, X.-Y. Fang and W. Shen, Chem. Eng. J., 210, 74 (2012), https://doi.org/10.1016/j.cej.2012.08.074

9 S. Mirmehdi, P. R. G. Hein, C. I. L. Sarantopoulos, M. V. Dias and G. H. D. Tonoli, Food Packag. Shelf., 15, 87

(2018), https://doi.org/10.1016/j.fpsl.2017.11.007

10 S. Mirmehdi, M. L. C. Oliveira, P. R. G. Hein, M. V. Dias, C. I. Sarantópoulos et al., J. Wood Chem. Technol., $\quad 38, \quad 233 \quad$ (2018), https://doi.org/10.1080/02773813.2018.1432656

11 F. Li, P. Biagioni, M. Bollani, A. Maccagnan and L. Piergiovanni, Cellulose, 20, 2491 (2013), https://doi.org/10.1007/s10570-013-0015-3

12 C. Salas, T. Nypelö, C. Rodriguez-Abreu, C. Carrillo and O. J. Rojas, Curr. Opin. Colloid. In., 19, 383 (2014), DOI:10.1016/j.cocis.2014.10.003

13 A. Svensson, E. Nicklasson, T. Harrah, B. Panilaitis, D. L. Kaplan et al., Biomaterials, 26, 419 (2005), https://doi.org/10.1016/j.biomaterials.2004.02.049

14 M. Nikolajaski, J. Wotschadlo, J. H. Clement and T. Heinze, Macromol. Biosci., 12, 920 (2012), https://doi.org/10.1002/mabi.201200040

15 C. S. Fonseca, T. F. Silva, M. F. Silva, I. R. C. Oliveira, R. F. Mendes et al., Cerne, 22, 59 (2016).

16 Y. Okahisa, A. Yoshida, S. Miyaguchi and H. Yano, Compos. Sci. Technol., 69, 1958 (2009), https://doi.org/10.1016/j.compscitech.2009.04.017

17 S. Ummartyotin, J. Juntaro, M. Sain and H. Manuspiya, Ind. Crop. Prod., 35, 92 (2012), https://doi.org/10.1016/j.indcrop.2011.06.025

18 A. C. C. Arantes, C. Almeida, L. Dauzacker, M. Bianchi, D. Wood et al., Carbohyd. Polym., 163, 101 (2017), https://doi.org/10.1016/j.carbpol.2017.01.007

19 N. R. T. Prado, J. Raabe, S. Mirmehdi, L. N. Hugen and L. Lima, Cerne, 23, 423 (2018).

20 P. Samyn, A. Barhoum, T. Ohlund and A. Dufresne, J. Mater. Sci., 53, 146 (2018), https://doi.org/10.1007/s10853-017-1525-4

21 M. M. S. Lima and R. Borsali, Macromol. Rapid Comm., 25, $\quad 771$ https://doi.org/10.1002/marc.200300268

22 G. H. D. Tonoli, M. N. Belgacem, J. Bras, M. A. P. Silva, F. A. R. Lahr et al., J. Mater. Sci., 47, 4167 (2012), https://doi.org/10.1007/s10853-012-6271-z

23 G. Siqueira, J. Bras and A. Dufresne, Biomacromolecules, $10, \quad 425 \quad$ (2009), https://doi.org/10.1021/bm801193d

24 A. Guimarães Jr., V. R. Botaro, K. M. Novack, W. P. Flauzino Neto, L. M. Mendes et al., J. Nanosci. Nanotechnol., $\quad \mathbf{1 5}, \quad 6751 \quad$ (2015), https://doi.org/10.1166/jnn.2015.10854

${ }^{25}$ G. H. D. Tonoli, K. M. Holtman, G. Glenn, A. S. Fonseca, D. Wood et al., Cellulose, 23, 1239 (2016), https://doi.org/10.1007/s10570-016-0890-5

${ }_{26}$ Y. Habibi, L. A. Lucia and O. J. Rojas, Chem. Rev., 110, 3479 (2010), https://doi.org/10.1021/cr900339w 
27 C. E. Wyman, S. R. Decker, M. E. Himmel, J. W. Brady, C. E. Skopec et al., in "Polysaccharides: Structural Diversity and Functional Versatility", (second ed.), edited by S. Dumitriu, New York, 2004, pp. 995-1033.

${ }_{28}$ S. Panthapulakkal and M. Sain, Int. J. Polym. Sci., 2012, 1687 (2012).

${ }^{29}$ G. H. D. Tonoli, E. M. Teixeira, A. C. Correa, J. M. Marconcini, L. A. Caixeta et al., Carbohyd. Polym., 89 , 80

(2012),

https://doi.org/10.1016/j.carbpol.2012.02.052

30 M. V. Scatolino, D. W. Silva, L. Bufalino, G. H. D. Tonoli and L. M. Mendes, Procedia Eng., 200, 155 (2017), https://doi.org/10.1016/j.proeng.2017.07.023

31 M. V. Scatolino, L. Bufalino, L. M. Mendes, M. Guimarães Jr. and G. H. D. Tonoli, Wood Sci. Technol., $\quad \mathbf{5 1}, \quad 1095 \quad$ (2017), https://doi.org/10.1007/s00226-017-0927-4

32 M. L. Hassan, A. P. Mathew, E. A. Hassan, N. A. El-Wakil and K. Oksman, Wood Sci. Technol., 46, 193 (2012), doi: 10.1007/s00226-010-0373-z

33 B. Wang, M. Sain and K. Oksman, Appl. Compos. Mater., 14, 89 (2007), https://doi.org/10.1007/s10443006-9032-9

34 S. Panthapulakkal and M. Sain, Polym. Plast. Technol. Eng., 2, 1 (2013).

35 A. Alemdar and M. Sain, Compos. Sci. Technol., 68 , 557

https://doi.org/10.1016/j.compscitech.2007.05.044

36 Y. Habibi, M. Mahrouz and M. R. Vignon, Food Chem., 115, 423 (2009), https://doi.org/10.1016/j.foodchem.2008.12.034

37 J. I. Morán, V. A. Alvarez, V. P. Cyras and A. Vázquez, Cellulose, 15, $149 \quad$ (2008), https://doi.org/10.1007/s10570-007-9145-9

38 R. Zuluaga, J. L. Putaux, J. Javier Cruz, J. Vélez, I. Mondragon et al., Carbohyd. Polym., 76, 51 (2009), https://doi.org/10.1016/j.carbpol.2008.09.024

39 S. Cheng, S. Panthapulakkal, N. Ramezani, A. M. Asiri and M. Sain, BioResources, 9, 4 (2014), https://ojs.cnr.ncsu.edu/index.php/BioRes/article/view/ BioRes_09_4_7653_Cheng_Aloe_vera_Rind_Nanofib ers

${ }^{40}$ S. Alila, I. Besbes, M. R. Vilar, P. Mutjé and S. Boufi, Ind. Crop. Prod., 41, 250 (2013), https://doi.org/10.1016/j.indcrop.2012.04.028

${ }^{41}$ F. Chang, S. H. Lee, K. Toba and A. Nagatani, Wood Sci. Technol., 46, 393 (2012), https://doi.org/10.1007/s00226-011-0416-0

42 H. D. Nguyen, T. T. T. Mai, N. B. Nguyen, T. D. Dang, M. L. P. Le et al., Adv. Nat. Sci.: Nanosci. Nanotechnol., 4, 1 (2013), DOI: 10.1088/20436262/4/1/015016

43 N. T. Phong, M. H. Gabr, K. Okubo, B. Chuong and T. Fuji, Mater. Design, 47, 624 (2013), https://doi.org/10.1016/j.matdes.2012.12.057

44 J. Zhang, H. Song, J. Zhuang, C. Pang and S. Liu, Biomass Bioenerg., 39, 78 (2012), https://doi.org/10.1016/j.biombioe.2010.06.013
45 W. Chen, H. Yu and Y. Liu, Carbohyd. Polym., 86, 453

(2011),

https://doi.org/10.1016/j.carbpol.2011.04.061

46 Y. Okahisa, K. Abe, M. Nogi, A. N. Nakagaito, T. Nakatani et al., Compos. Sci. Technol., 71, 1342 (2011),

https://doi.org/10.1016/j.compscitech.2011.05.006

47 M. Guimarães Jr., V. R. Botaro, K. M. Novack, F. G. Teixeira and G. H. D. Tonoli, Ind. Crop. Prod., 70, 72

(2015),

https://doi.org/10.1016/j.indcrop.2015.03.014

48 M. Nogi, S. Iwamoto, A. N. Nakagaito and H.

Yano, Adv. Mater., 21, $1595 \quad$ (2009), https://doi.org/10.1002/adma.200803174

49 Technical Association of the Pulp and Paper Industry-TAPPI: Test Method T $9 \mathrm{~m}-54$, Atlanta, USA, 1998.

50 Technical Association of the Pulp and Paper Industry-TAPPI: Test Method T $203 \mathrm{~cm}-09$. Atlanta, USA, 2009.

51 Technical Association of the Pulp and Paper Industry-TAPPI: Test Method T 222 om-11, Atlanta, USA, 2011.

52 Technical Association of the Pulp and Paper Industry-TAPPI: Test Method T $211 \mathrm{~cm}-07$, Atlanta, USA, 2007.

53 Technical Association of the Pulp and Paper Industry-TAPPI: Test Method T $204 \mathrm{~cm}-07$, Atlanta, USA, 2007.

54 B. L. Browning, "Methods of Wood Chemistry", vol. II, Wiley, New York, 1967, pp. 498.

55 F. Kennedy, G. O. Phillips and E. P. A. Williams, "Wood and Cellulosics: Industrial Utilization, Biotechnology, Structure and Properties", Chichester: E. Horwood, 1987, 1130 pp.

56 American Society for Testing and Materials-ASTM E 1721-01, Philadelphia, 2009.

57 American Society for Testing and Materials-ASTM E 1690-08, Philadelphia, 2008.

58 American Society for Testing and Materials-ASTM E 1755-01, Philadelphia, 2007.

59 SCAN standard C 4:61 Pentosans in pulp, 1961.

60 SCAN Standard C 1:77 Kappa number, 1977.

61 SCAN Standard C 7:62 Dichloromethane extract of pulp, 1962.

62 SCAN standard C 6:62 Ash in wood and pulp, 1962.

63 A. D. French, Cellulose, 21, 885 (2014), https://doi.org/10.1007/s10570-013-0030-4

${ }^{64}$ V. C. Correia, C. Viviane, V. Santos, M. Sain, S. F. Santos et al., Cellulose, 23, 2971 (2016), https://doi.org/10.1007/s10570-016-0996-9

65 C. F. Macrae, I. J. Gruno, J. A. Chisholm, P. R. Edgington, P. McCabe et al., J. Appl. Crystallogr., 41, 466 (2008) http://dx.doi.org/10.1107/S0021889807067908

${ }^{66}$ Y. Nishiyama, P. Langan and H. Chanzy, J. Am. Chem. Soc., 124, 9074 (2002), https://doi.org/10.1021/ja0257319 
67 S. Nam, A. D. French, B. D. Condon and M. Concha, Carbohyd. Polym., 135, 1 (2016), https://doi.org/10.1016/j.carbpol.2015.08.035

68 L. Segal, J. J. Creely, A. E. Martin and C. M. Conrad, Text. Res. J., 29, 10 (1959), https://doi.org/10.1177/004051755902901003

69 J. I. Langford and A. J. C. Wilson, J. Appl. Crystallogr., 11, 102 (1978), research papers https://doi.org/10.1107/S0021889878012844

70 M. Loelovich, A. Levkin and O. Figovsky, BioResources, 5, $1393 \quad$ (2010), https://bioresources.cnr.ncsu.edu/BioRes_05/BioRes_0 5_3_1393_Ioelovich_LF_Study_Cellulose_Paracrystal linity_988.pdf

71 J. E. M. Ballesteros, V. Dos Santos, G. Mármol, M. Frías and J. Fiorelli, Cellulose, 24, 2275 (2017), https://doi.org/10.1007/s10570-017-1253-6

72 American Society for Testing and Materials-ASTM D 790-03, Philadelphia, 2010.

73 American Society for Testing and Materials-ASTM E104-12, Philadelphia, 2012.

74 J. Raabe, A. S. Fonseca, L. Bufalino, C. Ribeiro, M. A. Martins et al., Carbohyd. Polym., 114, 424 (2014), https://doi.org/10.1016/j.carbpol.2014.08.042

75 J. Raabe, A. S. Fonseca, L. Bufalino, C. Ribeiro and M. A. Martins, J. Nanomat., 2015, 1 (2015).

76 N. Gontard, C. Duchez, J. L. Cuq and S. Guilbert, Int. J. Food Sci. Technol., 29, 39 (1994), https://doi.org/10.1111/j.1365-2621.1994.tb02045.x

77 S. Iwamoto, K. Abe and H. Yano, Biomacromolecules, 9, $1022 \quad$ (2008), https://doi.org/10.1021/bm701157n

78 K. L. Spence, R. A. Venditti, O. J. Rojas, Y. Habibi and J. J. Pawlak, Cellulose, 17, 835 (2010), https://doi.org/10.1007/s10570-010-9424-8

79 J. Lin, L. Yu, F. Tian, N. Zhao, X. Li et al., Carbohyd. Polym., 109, $35 \quad$ (2014), https://doi.org/10.1016/j.carbpol.2014.03.045

${ }^{80}$ C. Alves, P. M. C. Ferrão, A. J. Silva, L. G. Reis, M. Freitas et al., J. Clean Prod., 18, 313 (2010), https://doi.org/10.1016/j.jclepro.2009.10.022

81 K. M. Mannan and M. A. I. Talukder, Polymer, 38, $2493 \quad$ (1997), https://doi.org/10.1016/S00323861(96)00804-X

82 L. T. Chew, S. Rahim and K. Jamaludin, J. Trop. For. Sci., 4, 249 (1992).

83 U. L. Belini, M. Tomazello Filho, M. P. Chagas and C. T. Santos Dias, Rev. Árvore, 32, 523 (2008).

84 S. H. Brisola and D. Demarco, Sci. For., 39, 317 (2011).

85 Y. Qing, R. Sabo, J. Y. Zhu, U. Agarwal, Z. Cai et al., Carbohyd. Polym., 97, $226 \quad$ (2013), https://doi.org/10.1016/j.carbpol.2013.04.086

86 D. Klemm, B. Heublein, H. P. Fink and A. Bohn, Angew. Chem. Int. Ed., 44, 3358 (2005), https://doi.org/10.1002/anie.200460587
87 I. Besbes, M. R. Vilar and S. Boufi, Carbohyd. Polym., $\quad 84, \quad 975 \quad$ (2011), https://doi.org/10.1016/j.carbpol.2010.12.052

88 M. Pääkkö, M. Ankerfors, H. Kosonen, A. Nykänen, S. Ahola et al., Biomacromolecules, 8, 1934 (2007), https://doi.org/10.1021/bm061215p

89 A. D. French and S. M. Cintrón, Cellulose, 20, 583 (2013), https://doi.org/10.1007/s10570-012-9833-y

90 M. Poletto, O. J. Zattera and R. M. C. Santana, Bioresour. Technol., 126, 7 (2012), https://doi.org/10.1016/j.biortech.2012.08.133

91 R.P. Oliveira and C. Driemeier, J. Appl. Cryst., 46, 1196

(2013), https://doi.org/10.1107/S0021889813014805

92 Y. Cao, H. Tan, J. Mol. Struct., 705, 189 (2004), https://doi.org/10.1016/j.molstruc.2004.07.010

93 C. H. Chan, S. Zakaria, I. Ahmad and A. Dufresne, BioResources, $\quad 8, \quad 785 \quad$ (2013), https://ojs.cnr.ncsu.edu/index.php/BioRes/article/view/ BioRes_08_1_Chan_785_Cellulose_Kenaf_Core_Woo d

94 D. Ciolacu, F. Ciolacu and V. I. Popa, Cellulose Chem. Technol., 45, $13 \quad$ (2011), http://www.cellulosechemtechnol.ro/pdf/CCT12(2011)/p.13-21.pdf

95 J. Siroky, J. S. Blackburn, T. Bechtold, J. Taylor and P. White, Cellulose, 17, 103 (2010), https://doi.org/10.1007/s10570-009-9378-x

96 D. Ray and B. K. Sarkar, J. Appl. Polym. Sci., 80, 1013 (2001), https://doi.org/10.1002/app.1184

97 R. C. Sun, X. F. Sung, G. K. Liu, P. Fowler and J. Tomkinson, Polym. Int., 51, 2 (2002), https://doi.org/10.1002/pi.815

98 X. F. Sun, F. Xu, R. C. Sun, P. Fowler and M. S. Baird, Carbohyd. Res., 340, 1 (2005), https://doi.org/10.1016/j.carres.2004.10.022

99 J. E. White, W. J. Catallo and B. L. Legendre, J. Anal. Appl. Pyrol., 91, 1 (2011), https://doi.org/10.1016/j.jaap.2011.01.004

${ }^{100}$ M. Carrier, A. Loppinet-Serani, D. Denux, J. M. Lasnier, F. Ham-Pichavant et al., Biomass Bioenerg., 35, $298 \quad$ (2011), https://doi.org/10.1016/j.biombioe.2010.08.067

${ }^{101}$ L. O. Alberti, O. F. Souza, D. Z. Ducci and I. O. Barcellos, Mater. Sci., 775, 775 (2014).

102 D. P. Mobley, "Plastics from Microbes: Microbial Synthesis of Polymers and Polymer Precursors", Hanser Gardner Publications, Munich, 1994, 269 pp.

103 M. H. Hartmann, "Biopolymers from Renewable Resources", New York, 1998, pp. 367-411.

${ }^{104}$ I. Kajanto and K. Niskanen, "Paper Physics: Papermaking Science and Technology", Finland, 1998, pp. 223-259.

${ }^{105}$ G. H. D. Tonoli, A. E. F. S. Almeida, M. A. P. Silva, A. Bassa, D. Oyakawa et al., Holzforschung, 64, 595 (2010), DOI: https://doi.org/10.1515/hf.2010.073 